\title{
TINGKAT STRES DENGAN SIKLUS MENSTRUASI PADA MAHASISWA
}

\author{
Nety Mawarda Hatmanti * \\ Fakultas Ilmu Kesehatan UNUSA \\ E-mail: nety.mawarda@unusa.ac.id
}

\begin{abstract}
Stress can made abnormal of reproduction system expecially cycle of menstruate. Stress can lead to serious physical illness. Stress in student may influence cycle of menstruate. If this condition continue, can made the women to infertile.

This study is cross sectional design. The population were student in Program Studi S1 Ilmu Keperawatan Medicine Faculty of Airlangga University. Samples were recruited using consecutive sampling, and there were 57 samples who met the inclusion criteria. The observed variables were stress level and cycle of menstruate in fertile age student. Data were collected by questionare and observe. Then, data analyzed using Spearman Rank Correlation $(\mathrm{p}=0,000)$.

The result showed that 26 students $(46 \%)$ had moderate stress, 31 students $(54 \%)$ had severe stress. The analyze of cycle menstruate showed that 34 students $(60 \%)$ had cycle menstruate abnormal and 23 students (40\%) had cycle menstruate normal. By using analysis non parametric, Spearman's Rank Correlation the result showed that value correlation $(r)=0,464$. It is mean that there is enought correlation between stress level and cycle of menstruate in fertile age student.

Based on the conclution, we suggested to promote this information to the student about stress management. So, the cycle menstruste can normal.
\end{abstract}

Abstrak : stress level, cycle menstruate, nursing student.

Abstrak : Stres bisa menyebabkan sistem reproduksi yang abnormal khususnya siklus menstruasi. Stres juga dapat menyebabkan sakit fisik yang serius. Stres yang terjadi pada mahasiswa bisa mempengaruhi siklus menstruasi. Jika hal ini berlanjut maka bisa menyebabkan infertil.

Desain penelitian ini menggunakan cross sectional. Populasinya adalah mahasiswa Program Studi S1 Keperawatan Fakultas Kedokteran Universitas Airlangga. Pengambilan sampel menggunakan tehnik consecutive sampling dan menggunakan kriteria inklusi sehingga jumlah sampel ada 57 mahasiswa. Variabel yang diteliti adalah tingkat stres dan siklus menstruasi pada masa subur mahasiswa. Data didapat dari kuisioner dan observasi, kemudian dianalisis menggunakan korelasi Spearman $(\mathrm{p}=0,0000)$.

Hasil menunjukkan bahwa 26 mahasiswa berada pada tingkat stres sedang, 31 mahasiswa pada stres ringan. Analisis menunjukkan bahwa 34 mahasiswa mempunyai siklus menstruasi abnormal dan 23 mahasiswa mempunyai siklus menstruasi normal. Menggunakan analisis non parametrik Spearman didapatkan bahwa hubungan $(r)=0,464$ yang menunjukkan bahwa ada cukup hubungan antara tingkat stres dengan siklus menstruasi pada mahasiswa usia subur.

Dari hasil di atas, maka kita harus memberikan pendidikan tentang manajemen stress sehingga mahasiswa mempunyai siklus menstruasi yang normal. 


\section{PENDAHULUAN}

Setiap orang mengalami stres sepanjang kehidupannya. Stres dapat memberi stimulus terhadap perubahan dan pertumbuhan, dalam hal ini stres adalah positif dan bahkan diperlukan. Namun demikian, terlalu banyak stres dapat mengakibatkan penyesuaian buruk, penyakit fisik, dan ketidakmampuan untuk mengatasi atau koping terhadap masalah. Sejumlah penelitian yang telah dilakukan menunjukkan adanya hubungan antara peristiwa kehidupan menegangkan atau penuh stres dengan berbagai kelainan fisik dan psikiatrik (Potter\&Perry, 1999).

Menstruasi merupakan bagian dari proses reguler yang mempersiapkan tubuh wanita setiap bulannya untuk kehamilan. Siklus ini melibatkan beberapa tahap yang dikendalikan oleh interaksi hormon yang dikeluarkan oleh hipotalamus, kelenjar dibawah otak depan, dan indung telur. Menstruasi atau haid mengacu kepada pengeluaran secara periodik darah dan sel-sel tubuh dari vagina yang berasal dari dinding rahim wanita. Menstruasi dimulai saat pubertas antara umur 10 dan 16 tahun, tergantung pada berbagai faktor, termasuk kesehatan wanita, status nutrisi, dan berat tubuh relatif terhadap tinggi tubuh. Menstruasi berlangsung kira-kira sekali sebulan sampai wanita mencapai usia 45-50 tahun, tergantung pada kesehatan. Panjang rata-rata siklus menstruasi adalah 21-40 hari. Namun hanya $10-15 \%$ wanita yang memiliki siklus 28 hari (Medicastore, 2004). Panjang siklus dapat bervariasi pada satu wanita selama saat-saat yang berbeda dalam hidupnya, dan bahkan dari bulan ke bulan tergantung pada berbagai hal, termasuk kesehatan fisik, emosi, dan nutrisi wanita tersebut (Kesrepro.info, 2002). Semakin dewasa biasanya siklus menstruasi lebih teratur walaupun tetap saja bisa maju atau mundur beberapa hari karena faktor stres atau kelelahan (Pontianak Post, 2005). Menstruasi yang tidak teratur dapat disebabkan karena kondisi-kondisi seperti : stres yang mempengaruhi kerja hipotalamus, penggunaan obat, tumor kandungan (Barclay, 2006). Namun sampai saat ini penelitian tentang hubungan tingkat stres dengan siklus menstruasi usia subur belum jelas.

Banyak wanita mengalami ketidaknyamanan fisik selama beberapa hari sebelum periode menstruasi mereka datang. Kira-kira setengah dari seluruh wanita menderita akibat dismenorhea, atau menstruasi yang menyakitkan (Kesrepro.info, 2002). Terlambat haid atau menstruasi yang tidak teratur juga patut diwaspadai karena itu berarti telah terjadi abnormalitas pada siklus menstruasi (Hembing, 2006). Sebagian wanita mengalami haid yang tidak normal, diantaranya mulai dari usia haid yang datang terlambat, jumlah darah haid yang yang sangat banyak sampai-sampai harus berulang kali mengganti pembalut wanita, nyeri atau sakit saat haid, gejala PMS (Pre Menstruasi Syndrome), siklus haid yang tidak teratur dan masih banyak lagi. Gangguan ini jangan didiamkan karena dapat berdampak serius, haid yang tidak teratur misalnya dapat menjadi pertanda seorang wanita kurang subur (Pdpersi, 2005). Sekitar 1 dari 6-8 pasangan suami-istri adalah pasangan yang tidak subur, dan kirakira $60 \%$ dari pasangan tidak subur ini , infertilitas disebabkan karena sterilitas wanita (Guyton\&Hall, 1996). Berdasarkan pengambilan data dengan pembagian kuesioner pada 12 April 2007 kepada 51 mahasiswa angkatan A Program Studi S1 Ilmu Keperawatan Fakultas Kedokteran Universitas Airlangga, didapatkan sebanyak 18 orang mahasiswa mempunyai siklus menstruasi tidak teratur, diantaranya $77,8 \%$ pernah mengalami dysmenorhea, 38,9\% pernah mengalami sakit kepala saat menstruasi, $16,7 \%$ pernah pingsan pada saat menstruasi, $16,7 \%$ pernah tidak masuk kuliah karena menstruasi dan 44,4\% terganggu dalam mengerjakan tugas kuliah seperti : tidak mengikuti kegiatan kelompok, pengerjaan tugas tertunda, dan pemahaman terhadap materi kurang maksimal. Menurut pengambilan data awal untuk mengetahui penyebab stres pada 16 mahasiswa angkatan A Program Studi S1 Ilmu Keperawatan pada 8 Mei 2007 didapatkan hasil bahwa sebanyak $37,5 \%$ menyatakan ujian sebagai penyebab 
stres yang utama, 31,3\% menyatakan PBP di Rumah Sakit dr.Soetomo sebagi penyebab kedua stres, $50 \%$ menyatakan mengerjakan tugas kuliah seperti makalah sebagai penyebab ketiga stres, $68,8 \%$ menyatakan praktikum dan kegiatan ekstra di kampus sebagai penyebab terakhir dari stres di kampus.

Pada usia subur, stres sangat mempengaruhi pada keseimbangan hormonal, sehingga sering mengganggu siklus haid. Kondisi stres mempengaruhi hipotalamus yang merupakan pusat pengendalian hormon dari sistem reproduksi. FSH (follicle stimulating hormone) dan LH (luteinizing hormone) yang dihasilkan oleh hipotalamus menyebabkan produksi estrogen dan progesteron dari ovarium menjadi terganggu yang menyebabkan siklus menstruasi menjadi tidak teratur. Kadang-kadang, tidak ditemukan adanya kelainan pada organ genital wanita, yang mana harus dianggap bahwa ketidaksuburan tersebut disebabkan baik karena fungsi fisiologis yang abnormal dari sistem genetalia maupun karena perkembangan genetik yang abnormal dari ovum itu sendiri. Hal ini disebabkan karena hiposekresi hormon-hormon gonadotropin sehingga menyebabkan infertilitas pada wanita.

Berdasarkan pemaparan fenomena bahwa menstruasi pada mahasiswa angkatan A Program Studi S1 Ilmu Keperawatan Fakultas Kedokteran Universitas Airlangga menyebabkan dysmenorhea, sakit kepala saat menstruasi, pingsan saat menstruasi, pernah tidak masuk kuliah, terganggu dalam mengerjakan tugas kuliah, juga didukung oleh selama ini belum ada yang meneliti tentang hubungan tingkat stres dengan siklus menstruasi, maka peneliti mengangkat masalah ini dalam penelitian ini.

\section{METODE}

Dalam penelitian ini jenis yang digunakan adalah cross sectional. Populasi dalam penelitian ini adalah 57 mahasiswa angkatan A Program Studi S1 Ilmu Keperawatan Fakultas Kedokteran Universitas Airlangga.
Jadi besar sampel yang digunakan dalam penelitian ini adalah 57 responden. Pengambilan sampel dilakukan secara consecutive sampling dengan kriteria inklusi : mahasiswa yang mempunyai siklus menstruasi teratur sejak awal menarche; Mahasiswa yang belum menikah. Kriteria eksklusi : Mahasiswa yang mempunyai penyakit lain yang mempengaruhi keadaan hormonnya, misalnya kista ovarium, kelainan hormonal; Mahasiswa yang sedang menjalankan pengobatan atau terapi hormonal. Variabel independen adalah tingkat stres yang diukur dengan kuisioner yang dimodifikasi dari Stressless Inc. (2006) dan variabel dependen adalah siklus menstruasi yang diukur dengan kuisioner yang dimodifikasi dari teori Winkjosastro (2005) dan rubrik BKKBN (2006).

\section{HASIL DAN PEMBAHASAN a. Hasil}

Data khusus berisi tentang identifikasi tingkat stres yang dialami oleh mahasiswa Angkatan A Program Studi S1 Ilmu Keperawatan Fakultas Kedokteran Universitas Airlangga, pengukuran tingkat stres yang dialami oleh mahasiswa Angkatan A Program Studi S1 Ilmu Keperawatan Fakultas Kedokteran Universitas Airlangga, mengidentifikasi siklus menstruasi pada mahasiswa Angkatan A Program Studi S1 Ilmu Keperawatan Fakultas Kedokteran Universitas Airlangga, pengukuran siklus menstruasi pada mahasiswa Angkatan A Program Studi S1 Ilmu Keperawatan Fakultas Kedokteran Universitas Airlangga, dan mengidentifikasi hubungan antara tingkat stres dengan siklus menstruasi pada mahasiswa Angkatan A Program Studi S1 Ilmu Keperawatan Fakultas Kedokteran Universitas Airlangga.

1) Identifikasi Penyebab Stres

Tabel 1 Distribusi responden berdasarkan penyebab stres pada mahasiswa Angkatan A Program Studi S1 Ilmu Keperawatan Fakultas Kedokteran Universitas Airlangga 5-26 Juni 2007. 


\begin{tabular}{clcc}
\hline No & Penyebab Stres & Frekuensi & $\begin{array}{c}\text { Persentase } \\
(\%)\end{array}$ \\
\hline 1 & Ujian & 9 & 16 \\
2 & PBP & 7 & 12 \\
\hline 3 & Tugas Kuliah & 11 & 19 \\
\hline 4 & Praktikum & 15 & 27 \\
\hline 5 & Kegiatan ekstra & 15 & 26 \\
& kampus & & \\
\hline & Jumlah & 57 & 100 \\
\hline
\end{tabular}

Sumber: Data Primer, Juni 2007

Berdasarkan tabel 1 di atas diketahui bahwa sebanyak 15 orang mahasiswa (27\%) menyatakan penyebab stresnya dikarenakan praktikum dan kegiatan ekstra kampus.

2) Pengukuran Tingkat Stres

Tabel 2 Distribusi frekuensi responden berdasarkan tingkat stres pada mahasiswa Angkatan A Program Studi S1 Ilmu Keperawatan Fakultas Kedokteran Universitas Airlangga 5 - 26 Juni 2007.

\begin{tabular}{clcc}
\hline No & $\begin{array}{c}\text { Tingkat } \\
\text { Stres }\end{array}$ & Frekuensi & $\begin{array}{c}\text { Persentase } \\
(\%)\end{array}$ \\
\hline 1 & Ringan & 26 & 46 \\
2 & Sedang & 31 & 54 \\
\hline 3 & Berat & 0 & \\
\hline & Jumlah & 57 & 100 \\
\hline
\end{tabular}

Sumber: Data Primer, Juni 2007

Mahasiswa Angkatan A Program Studi S1 Ilmu Keperawatan Fakultas Kedokteran Universitas Airlangga sebanyak 26 mahasiswa (46\%) mengalami stres ringan, sebanyak 31 mahasiswa (54\%) mengalami stres sedang, dan tidak ada mahasiswa yang mengalami stres berat, hal ini sesuai dengan teori Potter\&Perry (1989) mengenai tingkat stres.

3) Identifikasi Keteraturan Siklus Menstruasi Sejak Awal menarche

Tabel 3 Tabel frekuensi responden berdasarkan keteraturan siklus menstruasi sejak awal menarche pada mahasiswa Angkatan A Program Studi S1 Ilmu Keperawatan Fakultas Kedokteran
Universitas Airlangga 5 - 26 Juni 2007

\begin{tabular}{clcc}
\hline Keteraturan & & \\
No. & $\begin{array}{c}\text { Siklus } \\
\text { Menstruasi } \\
\text { Sejak Awal } \\
\text { Menarche }\end{array}$ & Frekuensi & $\begin{array}{c}\text { Jumlah } \\
\text { n }(\%)\end{array}$ \\
\hline 1 & Teratur & 57 & 100 \\
\hline 2 & Tidak teratur & 0 & 0 \\
\hline & Jumlah & 57 & 100 \\
\hline
\end{tabular}

Sumber: Data Primer, Juni 2007

Mahasiswa Angkatan A Program Studi S1 Ilmu Keperawatan Fakultas Kedokteran Universitas Airlangga sebanyak 57 mahasiswa $(100 \%)$ mengalami siklus menstruasi teratur, hal ini sesuai dengan teori sistem reproduksi wanita tentang siklus menstruasi yang diungkapkan oleh Michael J.O \& Elliot E.P. (1994).

4) Pengukuran Siklus Menstruasi

Tabel 4 Tabel frekuensi responden berdasarkan siklus menstruasi pada mahasiswa Angkatan A Program Studi S1 Ilmu Keperawatan Fakultas Kedokteran Universitas Airlangga 5 - 26 Juni 2007

\begin{tabular}{clcc}
\hline No. & $\begin{array}{c}\text { Siklus } \\
\text { Menstruasi }\end{array}$ & Frekuensi & $\begin{array}{c}\text { Jumlah } \\
\mathrm{n}(\%)\end{array}$ \\
\hline 1 & Normal & 23 & 40 \\
\hline 2 & Terganggu & 34 & 60 \\
\hline & Jumlah & 57 & 100 \\
\hline
\end{tabular}

Sumber: Data Primer, Juni 2007

Mahasiswa Angkatan A Program Studi S1 Ilmu Keperawatan Fakultas Kedokteran Universitas Airlangga terdapat sebanyak 23 mahasiswa $(40 \%)$ mengalami menstruasi normal (jumlah skor menstruasi < 9), hal ini sesuai dengan teori sistem reproduksi wanita tentang menstruasi yang diungkapkan oleh Bobak, Lowdermilk, Jensen (2005).

5) Hubungan antara Tingkat Stres dengan Siklus Menstruasi

Tabel 5 Tabulasi Silang Hubungan antara Tingkat Stres dengan Siklus 
Menstruasi pada mahasiswa Angkatan A Program Studi S1 Ilmu Keperawatan Fakultas Kedokteran Universitas Airlangga

\begin{tabular}{lcccc}
\hline \multirow{2}{*}{ Menstruasi } & \multicolumn{3}{c}{ Tingkat Stres } & \\
\cline { 2 - 5 } & Berat & Sedang & Ringan & Total \\
\hline Normal $<9$ & - & 4 & 19 & 23 \\
\hline $\begin{array}{l}\text { Terganggu } \\
\geq 10\end{array}$ & - & 22 & 12 & 34 \\
\hline Total & & 26 & 31 & 57 \\
\hline
\end{tabular}

Sumber: Data Primer, Juni 2007

Berdasarkan tabel 5 menunjukkan bahwa ada hubungan antara tingkat stres dengan siklus menstruasi pada mahasiswa Angkatan A Program Studi S1 Ilmi Keperawatan Fakultas Kedokteran Universitas Airlangga. Terdapat 26 mahasiswa (46\%) mengalami stres sedang, 31 mahasiswa (54\%) mengalami stres ringan, dan tidak ada mahasiswa yang mengalami stres berat, hal ini sesuai dengan teori Potter\&Perry bahwa stres terdiri dari tiga tahapan yaitu stres ringan, stres sedang, dan stres berat. Dari tabel 5 juga terlihat bahwa sebagian besar responden mengalami menstruasi terganggu (skor menstruasi $\geq 10$ ). Sebanyak 34 mahasiswa $(60 \%)$ dengan menstruasi terganggu, dan sebanyak 23 mahasiswa (40\%) dengan menstruasi normal, hal ini sesuai dengan teori Manuaba. Seseorang dikatakan normal menstruasinya jika panjang siklus menstruasinya 21-35 hari, lama menstruasinya 3-8 hari, siklus menstruasinya tepat seperti bulan sebelumnya, dan tidak ada gangguan selama terjadinya menstruasi.

Dengan menggunakan uji statistik non parametrik, korelasi Spearman's rho (r) dengan tingkat kemaknaan $\alpha \leq 0,05$ didapatkan hasil korelasi nilai $\mathrm{r}=0,464$ dan nilai $\mathrm{p}=0,000$. Hasil statistik tersebut menunjukkan hubungan yang bersifat linear antara tingkat stres dengan siklus menstruasi pada mahasiswa Angkatan A Program Studi S1 Ilmu Keperawatan Fakultas Kedokteran Universitas Airlangga. Artinya, semakin tinggi tingkat stres yang dialami, semakin tinggi pula skor untuk menentukan menstruasi terganggu.

\section{b. Pembahasan}

Hasil penelitian menunjukkan penyebab stres pada mahasiswa Angkatan A Program Studi S1 Ilmu Keperawatan Fakultas Kedokteran Universitas Airlangga berbeda-beda. Dari 57 responden, sebanyak 9 mahasiswa (16\%) menyatakan bahwa penyebab utama stres di lingkungan kampus adalah ujian, 7 mahasiswa (12\%) menyatakan bahwa penyebab kedua stres di kampus adalah kegiatan PBP di RS dr Soetomo, 11 mahasiswa (19\%) menyatakan bahwa penyebab ketiga stres di kampus adalah tugas kuliah seperti mengerjakan makalah, 15 mahasiswa (27\%) menyatakan bahwa penyebab stres yang keempat di kampus adalah praktikum di laboratorium, 15 (26\%) menyatakan bahwa penyebab stres di kampus adalah kegiatan ekstra kampus. Menurut para peneliti dan ahli psikolog, stres pada jaman modern ini disebabkan banyaknya perubahan yang harus dihadapi sehingga menuntut adaptasi dan penyesuaian yang pesat, yang tidak mudah dicapai dan dilaksanakan individu dengan sama mudahnya (Singgih dkk, 2000). Sumber stres (stressor) pada seseorang berasal dari lima sumber (Rasmun, 2004). Pertama stressor biologik yang disebabkan karena mikroba, bakteri, virus dan jasad renik lainnya, hewan, bermacam tumbuhan dan makhluk hidup lainnya yang dapat mempengaruhi kesehatan. Kedua stressor fisik yang disebabkan karena perubahan iklim, alam, cuaca, suhu, geografi; yang meliputi letak tempat tinggal, domisili, demografi; berupa jumlah anggota dalam keluarga, nutrisi, radiasi, kepadatan penduduk, imigrasi, kebisingan, dll. Ketiga stressor kimia yang disebabkan oleh serum darah glukosa (dari dalam tubuh), obat, pengobatan, pemakaian alkohol, nikotin, kafein, polusi udara, gas beracun, insektisida, pencemaran lingkungan, bahan-bahan kosmetika, bahan-bahan pengawet, dll. Keempat stressor sosial psikologik yang disebabkan karena prasangka, ketidakpuasan terhadap diri sendiri, kekejaman (aniaya, perkosaan), konflik peran, percaya diri rendah, perubahan ekonomi, emosi yang negatif, dan 
kehamilan. Kelima stressor spiritual yang disebabkan karena persepsi negatif terhadap nilai-nilai ke-Tuhanan. Manifestasi klinik dari stres sangat individual, dan hekekatnya merupakan kumpulan dari beberapa hal yang berpengaruh. Antara lain jenis dan taraf berat ringannya stres, persepsi dan penderitaan yang dirasakan oleh orang yang mengalami stres (Mangindaan dalam Sutanegara, 1991). Hal inilah yang menyebabkan adanya perbedaan tingkat stres pada mahasiswa Angkatan A Program Studi S1 Ilmu Keperawatan Fakultas Kedokteran Universitas Airlangga. Tetapi dari semua hal di atas, yang paling penting adalah kemampuan individu dalam mengelola stres. Seberapapun beratnya stressor yang ada, jika individu mempunyai kemampuan manajemen stres yang baik maka tidak akan menimbulkan efek negatif bagi kesehatan. Memiliki manajemen stres yang baik berarti mempunyai kemampuan untuk menjadikan stressor sebagai suatu tantangan darpada ancaman. Stressor tidak akan berefek negatif bagi kesehatan jika dikelola dan dimanfaatkan dengan baik.

Hasil penelitian menunjukkan bahwa pada mahasiswa Angkatan A Program Studi S1 Ilmu Keperawatan Fakultas Kedokteran Universitas Airlangga sebanyak 26 mahasiswa (46\%) mengalami stres ringan, sebanyak 31 mahasiswa (54\%) mengalami stres sedang, dan tidak ada mahasiswa yang mengalami stres berat. Stres bersifat universality yaitu umum semua orang sama dapat merasakannya tetapi cara pengungkapannya yang berbeda atau diversity. Sesuai dengan karakteristik individu maka responnya terhadap stres berbeda-beda untuk setiap orang. Respon yang berbeda tersebut dikarenakan mekanisme koping yang digunakan oleh individu dengan sumber dan kemampuan yang berbeda, dan kemampuan individu dalam mengatasi stres berbeda pula, sehingga stres yang sama akan mempunyai dampak dan reaksi yang berbeda (Potter\&Perry, 1989). Potter\&Perry (1989) juga menyatakan bahwa stres terbagi menjadi tiga tingkatan. Pertama stres ringan yang biasanya tidak merusak aspek fisiologis, umumnya dirasakan oleh setiap orang, misalnya lupa ketiduran, kemacetan, dikritik; situasi ini biasanya berakhir dalam beberapa menit atau beberapa jam dan dampaknya tidak akan menimbulkan penyakit kecuali jika dihadapi terus-menerus. Kedua stres sedang terjadi lebih lama beberapa jam sampai beberapa hari contohnya kesepakatan yang belum selesai, beban kerja yang berlebih, mengharapkan pekerjaan baru, anggota keluarga pergi dalam waktu yang lama, situasi seperti ini dapat bermakna bagi individu yang mempunyai faktor predisposisi suatu penyakit koroner. Ketiga stres berat adalah stres kronis yang terjadi beberapa minggu sampai beberapa tahun, misalnya kesulitan financial dan penyakit fisik yang lama. Mahasiswa yang mendapatkan stressor sama, belum tentu mengalami tingkat stres yang sama pula. Tergantung dari cara penerimaan setiap mahasiswa terhadap stres yang dihadapi dan juga cara mengatasinya (mekanisme koping yang digunakan dalam menghadapi stres). Jika seorang mahasiswa mempunyai koping yang baik dalam menghadapi stres, maka stres yang diterima tdak akan mengganggu kesehatannya terutama dalam hal sistem reproduksi yaitu siklus menstruasi. Tetapi sebaliknya, jika seorang mahasiswa tidak memiliki koping yang baik dalam menghadapi stres, maka hal itu sangat berpengaruh terhadap kesehatan.

Hasil penelitian menunjukkan bahwa mayoritas responden yaitu sebanyak 57 mahasiswa (100\%) Angkatan A Program Studi S1 Ilmu Keperawatan Fakultas Kedokteran Universitas Airlangga mengalami menstruasi teratur. Sejak awal mahasiswa mengalami menarkhe, mereka mempunyai siklus menstruasi teratur. Responden penelitian tidak ada yang mempunyai siklus menstruasi tidak teratur. Menstruasi adalah produksi berulang dari estrogen dan progesteron oleh ovarium mempunyai kaitan dengan siklus endometrium yang bekerja melalui tahapan berikut ini : pertama proliferasi dari endometrium uterus; kedua perubahan sekretoris pada endometrium, dan ketiga deskuamasi dari endometrium (Guyton\&Hall, 1997). Sistem reproduksi dan segala aktivitasnya diatur oleh sebuah poros 
yang disebut poros Hipotalamus-PituitaryGonad (HPG). Hipotalamus merupakan bagian otak yang menghasilkan bermacam-macam hormon pemacu dan penghambat. Hormon pemacu biasa dinamakan releasing hormone (RH), sedangkan hormon penghambat dinamakan inhibiting hormone (IH). Jika kadar suatu hormon dalam tubuh sangat rendah, maka hipotalamus akan meningkatkan produksi hormon tersebut dengan cara mengirim lebih banyak hormon pemacu ke kelenjar pituitari. Berdasarkan sinyal tersebut, kelenjar pituitari akan memproduksi hormon yang dimaksud. Sebaliknya, jika kadar suatu hormon sangat tinggi di dalam darah, maka hipotalamus akan mengirimkan hormon penghambat untuk menurunkan produksi hormon tersebut. Faktor pertumbuhan diperkirakan juga mempengaruhi menstruasi pada seseorang. Jika seorang anak mengalami keterlambatan pada saat masa pertumbuhan, diperkirakan matangnya sistem reproduksi wanita juga mengalami keterlambatan. Hal ini juga sangat dipengaruhi oleh nutrisi pada saat masa pertumbuhan.

Hasil penelitian menunjukkan bahwa mayoritas responden mengalami menstruasi terganggu (skor menstruasi $\geq 10$ ), yaitu sebanyak 34 mahasiswa (60\%), dan hanya 23 mahasiswa (40\%) dengan menstruasi normal. Siklus menstruasi didefinisikan sebagai menstruasi yang berulang setiap bulan (medicastore, 2005). Siklus menstruasi dihitung dari hari pertama menstruasi sampai tepat satu hari sebelum menstruasi bulan berikutnya. Siklus menstruasi normal pada wanita berkisar antara 21-35 hari, sedangkan lama menstruasi berkisar 3-8 hari. Terjadinya menstruasi atau haid merupakan perpaduan antara kesehatan alat genetalia dan rangsangan hormonal yang kompleks yang berasal dari mata rantai aksis hipotalamus-hipofisisovarium. Oleh karena itu, gangguan menstruasi dan gangguan siklus menstruasi dapat terjadi dari kelainan kedua faktor tersebut. Menstruasi biasanya dimulai antara umur 10-16 tahun, tergantung pada berbagai faktor, termasuk kesehatan wanita, status nutrisi, dan berat tubuh relatif terhadap tinggi tubuh. Menstruasi berlangsung kira-kira sekali sebulan sampai wanita mencapai usia 45-50 tahun, sekali lagi tergantung pada kesehatan dan pengaruh-pengaruh lainnya (Kesrepro.info, 2002). Diperkirakan dari jumlah mahasiswa yang mengalami menstruasi terganggu, beberapa diantaranya juga dipengaruhi oleh faktor lingkungan, baik lingkungan dikampus, maupun lingkungan tempat tinggalnya. Hal ini berhubungan dengan mekanisme koping yang digunakan pada saat menghadapi stres dan dukungan dari lingkungan sekitarnya pada saat menghadapi stres.

Hasil penelitian menunjukkan bahwa mayoritas responden mengalami menstruasi terganggu (skor menstruasi $\geq 10$ ), yaitu sebanyak 34 mahasiswa (60\%). Sedangkan data yang diperoleh mengenai tingkat stres, diketahui bahwa mayoritas mahasiswa mengalami stres pada tingkat ringan dan sedang, tidak ada mahasiswa yang mengalam stres tingkat berat. Dari hasil ini menunjukkan bahwa tingkat stres yang ringan dan sedang berhubungan dengan siklus menstruasi pada mahasiswa Angkatan A Program Studi S1 Ilmu Keperawatan Fakultas Kedokteran Universitas Airlangga. Stres akan mempengaruhi hipotalamus untuk melepaskan CRH (Corticotrophin Releating Hormone), kemudian merangsang pelepasan ACTH (Adreno Corticotropic Hormone). ACTH mensekresi GnRH (Gonadotrophins Releating Hormone) yang memicu hipofisis anterior untuk mengeluarkan FSH (Follicle Stimulating Hormone) dan LH (Luteinizing Hormone) yang menyebabkan produksi estrogen dan progesteron di awal menstruasi turun sehingga terjadi menstruasi. Tapi jika saat menstruasi kita tidak mempunyai koping yang baik untuk mengatasi stres, maka yang terjadi adalah sebaliknya. Hipothalamus menghambat kerja GnRH (Gonadotrophins Releasing Hormone) sehingga menghambat hipofisis anterior dalam pengeluaran FSH (Follicle Stimulating Hormone) dan LH (Luteinizing Hormone), yang akhirnya membuat produksi estrogen dan progesteron meningkat di akhir siklus 
menstruasi dan menyebabkan menstruasi menjadi terlambat (Guyton A.C, 1997). Mekanisme koping yang tidak baik dari mahasiswa Angkatan A Program Studi S1 Ilmu Keperawatan membuat siklus menstruasi terganggu. Hal ini tentu saja tidak bisa dianggap remeh. Diperlukan sosialisasi tentang mekanisme koping yang baik dalam mengatasi stres yang diterima

\section{SIMPULAN}

1. Mahasiswa Angkatan A Program Studi S1 Ilmu Keperawatan Fakultas Kedokteran Universitas Airlangga mengalami stres yang disebabkan oleh : ujian, PBP, mengerjakan tugas kuliah, praktikum di laboratorium, kegiatan ekstra kampus.

2. Mahasiswa Angkatan A Program Studi S1 Ilmu Keperawatan Fakultas Kedokteran Universitas Airlangga sebagian besar mengalami stres ringan yang disebabkan oleh karena manajemen dalam menghadapi stres yang tidak baik.

3. Mahasiswa Angkatan A Program Studi S1 Ilmu Keperawatan Fakultas Kedokteran Universitas Airlangga sebagian besar memiliki siklus menstruasi yang teratur sejak awal mereka mengalami menarche.

4. Mahasiswa Angkatan A Program Studi S1 Ilmu Keperawatan Fakultas Kedokteran Universitas Airlangga sebagian besar mengalami menstruasi yang terganggu selama 3 bulan terakhir yang disebabkan oleh mekanisme koping yang tidak baik dalam menghadapi stres.

5. Tingkat stres mempunyai hubungan yang signifikan dengan siklus menstruasi pada mahasiswa Angkatan A Program Studi S1 Ilmu Keperawatan Fakultas Kedokteran Universitas Airlangga (korelasi cukup kuat).

\section{DAFTAR RUJUKAN}

Abraham C. \& Shanley E. (1997). Psikologi Sosial untuk Perawat. Jakarta : EGC, hal : 211-212.

Arikunto, S. (2006). Prosedur Penelitian : Suatu Pendekatan Praktik. Jakarta : Rineka Cipta, hal : 6-50.

Bagian Obstetri\&Ginekologi Fakultas Kedokteran Universitas Padjadjaran Bandung. Obstetri Fisiologi. Bandung : Eleman, hal : 73-95.

Barclay, L. (2006). AAP Issues Guidelines for Menstrual Cycle Evalution. http://www.medscape.com. Akses : 15 April 2007, pukul 09.00.

Bobak, Lowdermilk, Jensen (1999). Maternity Nursing. Edisi 5. Penerbit : Mosby, hal : 44-73.

Bobak, Lowdermilk, Jensen (2005). (Alih Bahasa Maria A. Wijayarini, Peter I. Anugerah). Buku Ajar Keperawatan Maternitas. Edisi 4. Jakarta : EGC, hal : 45-51.

De Cherney, Alan at all (2007). Lange Current Diagnosis \& Teratment Obstetrics \& Gynecology. Ed.10.United States of America : The McGraw-Hill Companies, Inc, hal : 128-132.

Georgia Reproductive Specialist (2006). Stress Management : What is Stress?. http://www.ivf.com/stress.html. Akses : 15 April 2007, jam 09.00.

Guyton, A.C. (1997). (Alih Bahasa Irawati Setiawan). Buku Ajar Fisiologi Kedokteran. Edisi 9. Jakarta : EGC, hal : 1294-1300.

Hawari, D. (2001). Manajemen Stress, Cemas, dan Depresi. Jakarta : Balai Penerbit 
Fakultas Kedokteran Universitas Indonesia, hal : 17-43.

Hembing (2006). Mencegah \& Mengatasi Penyakit Kewanitaan dengan Tumbuhan Obat. http//www.cyberhealth.com. Tanggal 9 April, jam 14.00.

Manuaba, I.B.G. (1998). Ilmu Kebidanan, Penyakit Kandungan, dan Keluarga Berencana : untuk Pendidikan Bidan. Jakarta : EGC, hal : 87-94.

Masten, Y. (1993). Obstetric Nursing. Penerbit : Mc Graw Hill, hal : 2-5.

Michael J.O \& Elliot E.P. (1994). The History of Obstetrics \& Gynaecology. New York : Parthenon Publishing Group, hal : 291-293.

Minjarez, D.A. (2000). Obstetrics and Gynecology Clinics of North America : Abnormal Uterine Bleeding in Adolescents. Nomer 1. Volume 27. ,hal : 63-67.

Nevid, S.J. \& Rathus A.S. \& Greene B. (2005). Psikologi Abnormal. Jilid 1. Edisi 5. Jakarta : Erlangga, hal : 135-141.

Niven, N. (1995). Psikologi Kesehatan : Pengantar untuk Perawat dan Profesional Kesehatan Lain. Edisi 2. Jakarta : EGC, hal : 120-122.

Notoatmodjo, S. (2005). Metodologi Penelitian Kesehatan. Jakarta : Rineka Cipta, hal : 10-35.

Nursalam (2003). Konsep dan Penerapan Metodologi Penelitian Keperawatan : Pedoman Skripsi, Tesis, dan Instrumen Keperawatan. Edisi 1. Jakarta : Salemba Medika, hal : 39-106.
Poerwandari K. (2006). Stres dalam Kehidupan Sehari-hari. http:// www.yayasanpulih.com. Tanggal 9 April 2007, jam 14.00.

Potter \& Perry (1999). Buku Ajar Fundamental Keperawatan. Edisi 4. Jakarta : EGC, hal : 476-481.

Prawirohardjo, S. (2002). Ilmu Kebidanan. Jakarta : Yayasan Bina Pustaka Sarwono Prawirohardjo, hal : 45-51.

Prawirohardjo, S. (2005). Ilmu Kandungan. Jakarta : Yayasan Bina Pustaka Sarwono Prawirohardjo, hal : 103-120, 204-229.

Price A.S. \& Wilson M.L. (1995). Patofisiologi : Konsep Klinis Prosesproses Penyakit. Buku 2. Edisi 4. Jakarta : EGC, hal : 1127-1129.

Rasmun (2004). Stress, Koping \& Adaptasi : Teori \& Pohon Masalah. Jakarta : Sagung Seto, hal : 7-27.

Smeltzer, S.C. (2002). (Alih Bahasa Agung W.). Buku Ajar Keperawatan Medikal Bedah. Edisi 8. Volume 1. Jakarta : EGC, hal : 123-137.

Stressless. Inc (2006). Stress Assessment and PersonalProgram.

http://www.stressless.com/stressquiz2.c fm. Tanggal 15 April 2007, jam 09.00.

Suliswati, dkk (2004). Konsep Dasar Keperawatan Kesehatan Jiwa. Hal : 22-36.

Townsend M. (1995). Psychiatric Mental Health Nursing. Philadelpia : FA Davis Company.

(2002). Kesehatan Reproduksi Remaja. http://www.kesrepro.info.com. Tanggal 9 April 2007, jam 14.00. 
(2005). Bias Wanita : Waspadai Gangguan saat Tamu Bulanan Datang.http://www.pdpersi.co.id.

Tanggal 19 April 2007, jam 14.00.

(2006). Gema Pria. http : www.rubrikBKKBN.co.id. Tanggal 26 Mei 2007, jam 08.30. 